DOI: https://doi.org/10.47405/mjssh.v6i4.753

\begin{tabular}{|c|c|}
\hline 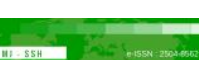 & Malaysian Journal of Social Sciences and Humanities (MJSSH) \\
\hline Malaysian Journal of & Volume 6, Issue 4, April 2021 \\
\hline (MJ-SSH) & e-ISSN : 2504-8562 \\
\hline & $\begin{array}{l}\text { Journal home page: } \\
\text { www.msocialsciences.com }\end{array}$ \\
\hline
\end{tabular}

\title{
Performance Appraisal Management in A Malaysian Secondary School
}

\author{
Peter Ong ${ }^{1}$, Md Jais Ismail ${ }^{2}$, Christina Sim Pei Pei ${ }^{3}$ \\ ${ }^{1}$ Cluster Of Education and Social Sciences, Open University Malaysia, Kuala Lumpur Learning Centre, Malaysia \\ ${ }^{2}$ Faculty of Music, Universiti Teknologi MARA, Shah Alam, Malaysia \\ ${ }^{3}$ Cluster Of Education and Social Sciences, Open University Malaysia, Tawau Learning Centre, Sabah, Malaysia \\ Correspondence: Md Jais Ismail (mdjais@uitm.edu.my)
}

\begin{abstract}
The purpose of this study is to explore the implementation of performance assessment in one of the Malaysian public secondary schools. Topics like what is a performance appraisal; the goal of having a performance appraisal in school; the processes for conducting performance appraisal at school; the benefits of having a performance appraisal in school; how performance appraisal affects school improvement; ways to improve performance appraisal in school; common problems with school performance appraisal are explored. There are six respondents have been selected in this case study including one principal and six teachers from an urban school in Malaysia. Eight open ended questions have been developed for the interview session with the principal and two open ended questions with teachers. Data were collected with personal in-depth interview and group interview. The results revealed that performance appraisal is important for the principal to track teachers' productivity, to improve their career, provide a brighter career pathway and help teachers to improve their job quality. Teacher in the other hand thought that the performance appraisal should have stringent criteria and fair evaluation. It is recommended that this process need a highly cooperation and two-way communication between both parties of principal and teachers.
\end{abstract}

Keywords: performance appraisal, case study, school management, career development, educational management

\section{Introduction}

Performance appraisal, in the context of an organization, is a performance review, career development discussion, or employee appraisal in which the job performance of an individual is reviewed, discussed, and evaluated. Performance management systems are used to align with an organization's resources to achieve the highest possible achievement. The performance level of the employees is reviewed and evaluated to determine the success or failure of the development of the organization. Therefore, the implementation of performance appraisal should be the top priority in organizations. In the context of education, teachers as academic staff and office workers as non-academic staff are the employees, and the board of administration at the school is the employer. Teachers play various roles at school such as conducting various interesting activities, managing students' assessment, understanding students' nature, and fulfilling students' educational needs (Md Jais \& Azu, 2020; Kamis et al., 2018). Hence, teachers' welfare including their performance appraisal should be thoroughly and fairly evaluated. 
Many reviews of the literature in Human Resource Management recognize the importance of the performance appraisal system that is carried out annually in the organization (Bayo-Moriones et al., 2020; DeNisi \& Murphy, 2017; Kadiresan et al., 2015). A school as an organization also faces the problem of directing the effort of its staff to achieve its goals and objectives. In doing so, the school needs to influence and channel the attitude of the teachers to optimize their contributions. Teachers are the essential resources in the school. The strategies have been used effectively for teachers according to their different needs and areas that they need to support. However, the researcher finds that little attention is paid to improving the teacher performance appraisal system. This study is taken to clarify certain questions related to the implementation of performance appraisal through regular evaluation of teacher performance and ways to effectively implement them toward goals that focus on teacher attention and effort. at school.

\section{Performance appraisal}

In education, teachers perform well when they are productive. Productivity refers to both effectiveness and efficiency (Kiran, 2020). Effectiveness refers to achieving the goal. However, it does not involve the cost of achieving the goal. Efficiency of teachers is needed. Efficiency evaluates the relationship between inputs consumed and outputs achieved between teachers and non-academic staff (Phillips et al., 2020). The measure of teacher productivity does not include the number of units produced or the percentage of crimes solved. The productivity of teachers is instead measured in terms of effectiveness and efficiency. Performance includes personnel data such as contributions, turnover, absences and delays. A good teacher is someone who not only performs well in terms of productivity, but also minimizes problems for the school by working on time, not wasting days and minimizing the number of work-related contributions. Evaluations are judgments about the characteristics, traits and performance of teachers. Evaluation of teachers' worth and identification of their strengths and weaknesses. Performance appraisal is a systematic evaluation of teachers by the principal (MéridaLópez \& Extremera, 2017). Teachers want to know their position in the school. Assessments are needed to make decisions by the principal on selection, training, promotion, transfer, and salary increment. In addition, they help in the search for staff.

Performance appraisal is a systematic and objective way of assessing a teacher's ability to perform her task (Widyasari, 2019). Hence, it helps to identify teachers who are doing their assignments well and those who are not. Performance appraisal has been defined by many scholars in various ways. According to Dale (1975), performance appraisal is a systematic assessment of the individual's performance at work and their development potential. According to Randall (1999), performance appraisal is a formal and structured system for measuring and evaluating the performance of employees in the organization in relation to their behavior and achievements and to obtain how and why the employee is currently performing their duty and how the employee can perform their duties more effectively in the future for the benefit of the organization. According to David (2015), performance appraisal is the process of evaluating the performance and qualifications of employees related to his job for which he is employed, for administration uses including placement, selection for promotions, provision of financial rewards.

According to Dale (1970), performance appraisal is used to evaluate the personalities, contributions and potentials of group members in a work organization. It is a continuous process of obtaining the information necessary to make correct and objective decisions about employees. Performance appraisal from an employee perspective, it aims to help employees realize their strengths and weaknesses and receive rewards accordingly. According to Dessler (2011), performance appraisal is the evaluation of the employee's performance by comparing their current performance with established standards, subsequently providing feedback to employees on their level of performance in order to improve their performance for the benefit of the organization.

According to Abdijabbar (2018), performance appraisal serves to ensure that organizations have a clear, consistent and fair approach to evaluation. Performance appraisal is used to recognize, evaluate and improve employee performance. Help decide performance expectations and discuss them with 
employees. Determines whether performance expectations have been met and how well they have been met. Helps set goals for years to come and encourage staff development. Record employee performance and inform employees of any performance strengths and weaknesses. It also serves as a point of reference in making promotional decisions and further declare the quality and results of employee work.

\section{School Management}

According to Diksha (2014), the school is managed effectively taking into account the needs and requirements of the internal and external resource structures of the school employees. Human resources are managed to improve job quality, job satisfaction and enjoyment, as well as professional practices at school. Diksha (2014) affirms that management is a model to follow found in all human organizations. It is a process that organizes and controls a social organization. According to him, management is the process of planning, managing, guiding, exceeding the efforts of members of the organization and using other resources to achieve goals. According to Kneizvich (1975) school management is a social process that identifies, rehabilitates, stimulates and controls to achieve the objectives set. Lunenburg (1996) has said that school management is a process of coordination of efforts between different members to achieve the objectives of teaching. Lunenburg (1996) observed that human resources are managed in a planned way. In addition to distributing, preparing, and disseminating job descriptions, he evaluates job performance in a comprehensive, balanced, and objective manner, as needed, according to instructions. Human resource development is managed in a planned manner. Plan and implement professional development programs, evaluate the effectiveness of the program and follow it as needed, tracking current progress in education service comprehensively and continuously.

Lunenburg (1996) noted that school property are managed for the convenience, comfort, and safety of schoolchildren. Movable and immovable property are managed in a planned manner. Prepare real and personal property, use it, maintain it, record and monitor the results of inspections in a comprehensive and consistent manner, as required. Financial management is organized to ensure that each expense provides the maximum benefit. Finances are managed in a planned way. Regulatory assessment, cost implementation and compliance. Monitoring of costs as a result of holistic and necessary compliance Educational resources are organized to help improve the quality of education. Educational resources are managed in an orderly manner. School management provides comprehensive and consistent regulation, monitoring the use of educational resources as needed, storing, utilizing, recording and implementing them. Lunenburg (1996) observed that the environment have succeeded in respecting the well-being of school students in fulfilling their responsibilities.

The physical environment of the school culture is systematically maintained and planned. In addition to developing protective properties with the appropriate procedures, it cleans, illuminates and restores the physical environment, following the necessary procedures and continuously. A relaxed and harmonious atmosphere is created in a planned way. Implement school rules and regulations in accordance with consistent, comprehensive and established rules, plan and implement privacy improvement programs appropriately. The understanding, acceptance and appreciation of the diversity of religions, races, cultures and languages was achieved to promote unity. A strategic consensus is formed to improve students' learning ability.

Findings from Zvavahera (2013) study has proven that the current performance management system did not improve the delivery of quality services in public administration because employees could not determine any merit in its application. Roger sumlin (2014) had done the research on performance management - "Impacts and trends" The results of the study showed that every organization needs to discover its own performance appraisal system. Xavier, J.V. (2015) conducted a study on the effectiveness of performance appraisal system and its influence with the socio-demographic factors of the employees of a manufacturing industry in Tamil Nadu. Khushbu S. Dave (2014) had conducted research on Paper on Performance Appraisal of Nurses in Hospitals. The results showed that the nurses' performance appraisal system needs to be improved to achieve better results. Participation of 
nurses in their assessment can build assessment systems more effectively, easily and meaningfully. Idowu (2017) wrote about the effectiveness of the performance appraisal system and its effect on employee motivation.

\section{Purpose of Research}

The aim of this study is to explore the implementation of performance appraisal in one of the secondary schools in Kuala Lumpur. Issues such as what a performance appraisal is; the objective of having performance appraisal in school; the processes of carrying out the performance appraisal in school; the advantages of having performance appraisal in school; how the performance appraisal affect the school improvement; the ways to improve performance appraisal in school; the common problems with performance appraisal in school will be discussed. Hence, four research questions have been develop in order that are; 1 . Is the process of the performance appraisal carried out successfully in school?, 2. What are the strength of having performance appraisal in school?, 3. How to improve performance appraisal in school?, 4. What are the common problems with performance appraisal in school?

\section{Research Objectives}

The objective of this study is to explore the implementation of performance assessment in one of the Kuala Lumpur public secondary schools. Topics like what is a performance appraisal; the goal of having a performance appraisal in school; the processes for conducting performance appraisal at school; the benefits of having a performance appraisal in school; how performance appraisal affects school improvement; ways to improve performance appraisal in school; Common problems with school performance appraisal are discussed.

\section{Methodology}

\section{Research Design}

This is a qualitative study adapting a case study method recommended by Kardos \& Smith (1979), case studies are conducted due to activities, events or problems that describe the real situation or as imagined and include the constraints of a person who will face in the workplace or in a situation experienced by the researcher. Case studies are used to help researchers see how the complexity of real life affects a decision. Case study analysis requires researchers to practice applying their knowledge and thinking skills to real situations. Merriam (1998) mentioned that to know the results of case study analysis the researcher should have high reliability to the reader (any case containing resolution, personality, sequence of events, problems and conflicts) It contains enough information for the reader with the aim of treating a problem and the issues discussed. It consists of various parts and each part usually ends with a problem and content for discussion. It is also possible that each problem discussed is not a clear end point to a situation under study. It is taken from real life (real identity can be kept secret).

According to Kardos and Smith (1979), Hamel et al. (1993), a good case study has the following characteristics: Case study is one of the most commonly used approaches as it is capable of supporting the investigation in more depth and more detail for each case and it is necessary to answer questions in the form of how and why. Case study research is also used to study current events related to behavior that cannot be manipulated. Usually, case study research uses a variety of evidence obtained from different sources, such as documents, artifacts, interviews and observations, as well as from various sources of evidence that may be available in previous studies. The advantage of a case study is the ability to conduct an investigation of a phenomenon in its context and it is not necessary to mimic a phenomenon in a laboratory or an experimental setting in order to better understand a phenomenon. Case study research can be based on any combination of quantitative and qualitative approaches. 
Typically, it uses a variety of data sources including two or more sources such as detailed direct observations, interviews, and documents. In addition, case studies can involve single or more cases.

\section{Sample}

There are six respondents have been selected in this study using convenience sampling method. This study has been conducted on 6 January 2021. The respondents are among one principal and five teachers who are teaching in a secondary school in Kuala Lumpur, Malaysia. The detail of respondents is shown as Table 1.

Table 1: Respondents

\begin{tabular}{llll}
\hline Respondents & Gender & Working Experience & Subject Expert \\
\hline Principal & Male & 30 years & Malay Language \\
Teacher1 & Female & 8 years & English \\
Teacher2 & Female & 8 years & History \\
Teacher3 & Male & 10 years & Mathematic \\
Teacher4 & Male & 7 years & Science \\
Teacher5 & Male & 8 years & Malay Language \\
\hline
\end{tabular}

\section{Data Collection}

There are two types of interview have been applied in this study that are personal in-depth interview and group interview. The personal in-depth interview has been conducted for the principal while the group interview was for the teachers. Eight open ended interview questions are set to be used in the interview session with the principal including:

1. What is a performance appraisal?

2. What is the objective of having performance appraisal in school?

3. What are the processes of carrying out the performance appraisal in your school?

4. How often is it being carried out?

5. What are the advantages of having performance appraisal in your school?

6. How the performance appraisal affects the school improvement?

7. What are the ways to improve performance appraisal in your school?

8. What are the common problems with performance appraisal in your school?

While there are four questions have been developed for the teachers including:

1. What is the objective of having performance appraisal in school?

2. What are the common problems with performance appraisal in your school?

Open-ended questions are used to ensure the participants are free to give saturated answers and express their ideas. Findings are based on the data collected from the interview with the principal and teachers, and a report and discussion of the findings are discussed. The interview has been conducted in the morning at 10.00 am after obtained permission from the school administration. The interview session with the principal took 60 minutes while with the teachers took 50 minutes.

\section{School background}

The school chosen in this case study is an excellent cluster school located in Kuala Lumpur. It was founded in 1958. The school has around 1200 students ranging from form 1 to form 5. In 1958 it was established as a Malay secondary school. In 1987, the school was classified as a controlled school. In 1999 it was chosen as one of the pioneering smart schools. In 2006 it was selected as a pioneer project school in open source software. In 2007, the school was announced as a cluster school. In 2010 it was proclaimed a high performance school. The school's niches are swimming and English language skills such as creative writing, public speaking, drama, choral speaking and debating. In 2015, the school was proclaimed as a cluster school of excellence to the present day. 


\title{
Findings and Discussion
}

\section{Objectives of Performance Appraisal}

Based on the interview from the principal and teachers of the school, several performance appraisal objectives are attached. They mentioned that the aim of having performance appraisal in school is to maintain records to determine pay packages, wages and salary increases, employee selection, promotion and transfer. Secondly, it is used to identify the strengths and weaknesses of employees to put them in the right job. Next, it is to maintain and evaluate the performance of employees in the organization for further growth and development. Besides, it is to provide feedback and review to employees on their performance and related status in the organization. Furthermore, it acts as a basis for influencing the work habits of the organization's employees. Lastly, it is to obtain feedback and review and maintain promotion and training programs for employees of the organization. The principal said,

\begin{abstract}
'hmmm... I think the main purpose of performance appraisal is to investigate the performance level of employees, then determine whether training is required for them or to promote them with an additional salary increase. Yes...it is the tool to determine whether the employee should be promoted, demoted, or fired due to poor performance in the organization.'
\end{abstract}

For teachers, they cannot be fired. The only way is to transfer them to another school. The principal and teachers agreed that in the education system employees refer to the academic and non-academic staff of an institution or school. The employer may be referred to the board of directors or the district officer.

\section{Performance Appraisal Process}

According to the principal, performance appraisal is generally done on a systematic basis. First, supervisor measures employee compensation and compare it to goals and plans. Next, the supervisor analyzes the job performance of the employees. Finally, employer guides employees to better performance. A personal discussion may arise between the employer and the employee due to a poor performance appraisal to further improve the benefit of the organization (Flores, 2012).

\section{Benefits of Performance Appraisal}

Based on the interview from the principal, performance appraisal is believed as a tool for the organization. It can be justified by the following transcription:

\begin{abstract}
'Performance appraisal helps the school principal to develop effective teacher promotion programs. These ineffective teachers can be fired or demoted. Secondly, performance appraisal helps the principal cancel compensation packages for teachers. Merit evaluation is used in performance appraisal. Performance appraisal seeks to recognize the performance of a teacher. Compensation packages such as bonus, salary increase, fringe benefits, assignment, and promotion are dependent on performance appraisal. The principal mentioned that the criteria used should measure merit and not seniority'.
\end{abstract}

Next, performance appraisal helps the principal determine training policies and programs. Helps the principal analyze the strengths and weaknesses of teachers so that new jobs can be designed for effective teachers. It also helps define future development programs for the school. The principal implied this process like working in a company. He said,

'Aha ...yes...performance appraisal helps the manager understand the validity and importance of the selection processes. The director knows the validity, strengths 
and weaknesses of the selection processes. Help in future changes and development of the school'.

Besides, effective communication between the principal and teachers is very important. Through performance appraisal, communication can be achieved in the following ways: First, the principal can understand and accept the abilities of the teachers' subordinates. Later, even subordinates can understand and build trust in superiors. In addition, it helps to maintain a friendly and pleasant work management relationship at the school. Last but not least, it develops the spirit of work and increases the morale of the teachers in the school.

The principal has also considered that performance appraisal serves as a motivational tool. Through the evaluation of teacher performance, its efficiency can be determined if the objectives are achieved. This motivates a teacher for compensation packages and also helps him to continue improving her performance in the future for the benefit of the school.

\section{Performance Appraisal and School Improvement}

The principal believed that school improvement includes excellent performance from all teachers and focuses on data-driven processes that are linked to the evaluation of teacher performance, it can be very powerful in guiding the school toward the common mission of achieving success and the development of students. The principal said,

\section{'hmm, well....linking school improvement with evaluating teacher performance creates a system in which all teachers focus on the school's goals and each teacher understands her role in achieving these goals'.}

On top of that, if teacher performance appraisal replaces traditional teacher appraisals, it certainly builds trust and professional collaboration in school.

\section{Suggestions to Improve Performance Appraisal}

According to Susan (2019), principals in large schools are often required to adhere to a particular method of evaluating teacher performance. According to the principal, not all managers have the ability to impact or improve the overall performance appraisal system they are in. However, any director can take the system in which he was treated and transform the performance appraisal process into a positive, rewarding and beneficial method for both him and the teachers who report to him. Principals can improve their performance appraisals and turn them into effective communication, goal setting, and development tools for teachers while operating within the requirements of their performance appraisal system. Principals can implement the recommendations in this performance development planning process and this performance development process checklist. As a result, principals can end up with the required performance appraisal document to make the performance appraisal process useful.

Furthermore, principals can make sure the teacher is clear about her goals for accomplishing the assignment. Teachers can rest assured that any component of their boss's process that causes the principal to rate or limit the performance of teachers is minimized. The principal can use the evaluation document as a starting point for discussion. He can use it periodically, at least quarterly, throughout the year to assess the teacher's progress. According to the principal, the performance appraisal document is a useful discussion starter that consolidates teacher performance information in one place. The performance appraisal report provides a record of discussions about teacher performance throughout the year. Provides a snapshot of the teacher's achievement and progress throughout the year. The principal can provide regular feedback to teachers, not just in the annual performance review. According to the teachers, they like regular feedback and effective principals take the time to provide feedback to them every day. They suggested that the principal can engage teachers in a two-way discussion whenever their performance does not meet the standard. The teachers said, 
'The principal can improve performance appraisal by involving the teacher in discussion throughout the year. The official performance review is just an extension of the normal performance discussion'.

In the other hand, the principal realized that he should make the conversation positive, empowering, and developmental for teachers. He can use sample questions to develop an effective self-assessment module for teachers in the performance appraisal process. The principal mentioned that effective performance appraisal relies on teachers to perform well. Consequently, setting performance goals is very important, but how the principal sets the goals with the teacher is the most important factor. He should set goals in order to strengthen teachers' ability to plan and implement the steps to achieve the goal. He agreed that the performance appraisal should support and strengthen the empowerment of teachers.

\section{Common Problems with Performance Appraisal}

According to Susan (2019), performance appraisals are conducted annually at the school. Teachers need feedback and goal planning more often than every year. They need weekly, even daily performance feedback. According to the teachers, feedback keeps them focused on their important goals. It also provides them with developmental training to help them increase their ability to contribute. Feedback recognizes them for their contributions. They all agreed that feedback is important.

The principal mentioned that teaching performance is constantly evaluated for its relevance, importance and contribution. They need changes so frequently that only agile responds in a timely manner. Don't turn performance grades into a one-way lesson in how teachers have done well this year and how they can improve.

According to the principal, the purpose of performance appraisal is to provide developmental feedback that will help teachers continue to grow in their skills and ability to contribute to the school. Performance reviews are often skewed when teachers link performance reviews to their pay increase. When performance appraisal is a factor that increases teachers' salaries, you lose the ability to help them learn and grow.

Injustice arises when some teachers are good at showing their performance in front of the principal. In reality, these teachers are devoid of responsibility in their teaching and learning processes.

\section{Sociodemographic Factors}

According to the principal, most of the teachers (53\%) in the school are in the age group under 30 years. The results show that this school has more young human resources. Most of the teachers $(55 \%)$ are male teachers. (30\%) the teachers are not married. It shows that there are more recently hired teachers. Most of the teachers (72\%) have more than 5 years of teaching experience. It is good practice and a good sign of the school to have many experienced teachers. There are no inexperienced teachers or temporary teachers in this school.

\section{Performance Appraisal System}

Based on the information given by the principal, the current performance appraisal system at this school is good when it helps teachers identify areas for improvement. Teachers have an adequate knowledge of the performance appraisal system that helps to assess teacher training needs. Performance appraisal helps school teachers understand their abilities and disabilities. Although it has to be held annually, it is held periodically at this school. All teachers have the opportunity to express their views on the performance appraisal system. Performance appraisal results are properly announced to teachers, reflecting actual teacher performance and further contributing to increasing teacher job efficiency. Teachers themselves have comments about unfairness in performance appraisal where the principal gives high marks to those teachers who can please the principal and lack 
responsibility in their teaching and learning processes in the classroom, such as the assignments of students who do not they are efficiently reviewed and scored.

\section{Conclusion and Recommendation}

Performance appraisal is performance review, performance appraisal, career development discussion, or teacher appraisal where a teacher's job performance is reviewed, discussed, and evaluated. Performance management systems are used to align with school resources to achieve the best possible outcome. The performance level of teachers is reviewed and evaluated to determine the success or failure of school development. Therefore, the implementation of performance appraisal should be the highest priority in the school. Teacher performance appraisal is necessary at the school to achieve goals. It is the responsibility of the school to provide proper training and improve the efficiency of teachers in a better way. All teachers at this school are considered valuable assets. Your progress is closely tied to performance. This study clearly shows that the performance appraisal system in this school is good and effective and has a high influence on sociodemographic factors.

In conclusion, a performance appraisal is one of the most important factors in any school and also a great tool for tracking teacher productivity. Every school should have established goals and objectives and every teacher should participate in the process as mentioned by Md Jais et al. (2018). Additionally, conducting a performance appraisal will improve productivity and also morale for teachers. Assessments are a positive way for the principal to let teachers know how well they are doing on their assignments. Sometimes teachers get involved in their work and do not realize what the school is trying to do for them. Whether the reward is a poor annual dinner or a simple thank you card, your work is recognized. Also, teachers should be grateful for any job they may have, because the school does not need to hire any media. Your commitment and contribution to the school is greatly appreciated. Having two-way communication is important in performance appraisal. This is my proposed solution for conducting performance appraisal in school. Both the principal and the teacher agreed with this proposed solution. Two-way communication helps us feel and understand what we share. It helps us listen as much or sometimes even more than we speak. We hear what is mentioned. Comments are provided to frame future communications. The principal checks for understanding regularly to confirm a meaning shared with her teachers. Two-way communication helps gather information from teachers and demonstrate its importance to the school. It also helps create a critical framework to support teacher participation. Two-way communication involves dialogue and conversation. When two-way communication is well planned, benefits for schools include increasing levels of job satisfaction by providing an outlet for teachers' concerns, ideas, and opinions; increase productivity by reducing ambiguity regarding roles, responsibilities and actions; greater collaboration across the school, which can have more creativity and innovation; increased trust between principal and teachers to build internal brand loyalty and provide opportunities for future growth (Rorlinda et al., 2020).

\section{Acknowledgement}

The publication of this study is funded by Universiti Teknologi MARA. No conflict of interest as a result of this study.

\section{References}

Abdijabbar, Ismail Nor. (2018). Performance Appraisal Policy (Theory and Practice). International Journal of Scientific and Research Publications, 8(9).

Bayo-Moriones, A., Galdon-Sanchez, J. E., \& Martinez-de-Morentin, S. (2020). Performance appraisal: dimensions and determinants. The International Journal of Human Resource Management, 31(15), 1984-2015. 

DOI: https://doi.org/10.47405/mjssh.v6i4.753

Chron. (2018). Expectations vs. job description. Retrieved from https://work.chron.com/expectations-vs-job-description-20645.html

Dale, S.B. (1975). Managing people at work: reading in personnel. Macmillan. University of Michigan.

Dale, Y. (1970). Personnel management and industrial relations. Prentice-hall.

Darling-Hammond, L., Amrein-Beardsley, A., Haertel, E., \& Rothstein, J. (2012). Evaluating teacher evaluation. Phi Delta Kappan, 93(6), 8-15.

David, K.H. (2015). Human resources management in the hospitality industry. Wiley.

DeNisi, A. S., \& Murphy, K. R. (2017). Performance appraisal and performance management: 100 years of progress?. Journal of applied psychology, 102(3), 421.

Dessler, G. (2011). Human resource management. Boston, MA: Pearson.

Diksha, K. (2014). Educational administration: meaning, nature and other details. Your article library.

Flores, A. A. (2012). The implementation of a new policy on teacher appraisal in Portugal: how do teachers experience it at school? Educational Assessment, Evaluation and Accountability, 24(4), 351-368.

Gohari, P., Ahmadloo, A., Boroujeni, B., \& Hosseinipour, J. (2013). The relationship between rewards and employee performance. Interdisciplinary Journal of Contemporary Research in Business, 5(3), 543-570.

Grund, C. and Przemeck, J. (2012). Subjective performance appraisal and inequality aversion. Applied Economics, 44(2), 2149-2155.

Hamel, J. , Dufour, S. , \& Fortin, D. (1993). Case study methods. In Qualitative research methods (Series 32). Newbury Park, CA: Sage.

Idowu, A. (2017). Effectiveness of performance appraisal system and its effect on employee motivation. Nile Journal of Business and Economics, 3. 10.20321/nilejbe.v3i5.88.

Kadiresan, V., Selamat, M. H., Selladurai, S., Ramendran, C. S., \& Mohamed, R. K. M. H. (2015). Performance appraisal and training and development of human resource management practices (HRM) on organizational commitment and turnover intention. Asian Social Science, 11(24), 162.

Kamis, M.S., Lubis, M.A., Mohamad, N., Kasim, A.A.M., Ismail, M.J. (2018): A review of teaching reading arabic text: cultivating curiosity for gifted students in the classroom. Asean Comparative Education Research Journal On Islam And Civilization (ACER-J) 2(2): 5974.

Kardos, G. , \& Smith, C. O. (1979). On writing engineering cases. Proceedings of the American Society for Engineering Education National Conference on Engineering Case Studies, Ottawa, Ontario, Canada.

Khushbu, S. D. (2014). Research paper on performance appraisal of nurses in hospitals (with specific reference to saurashtra region). Indian journal of applied research, 4(5).

Kiran, D. R. (2020). Work Organization and Methods Engineering for Productivity. ButterworthHeinemann.

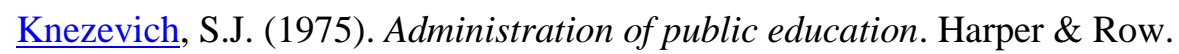

Lunenburg, F. C. (1996). Educational administration : concepts and practices. Belmont :Wadsworth Pub. Co.

Maley, J. (2013). Hybrid purposes of performance appraisal in a crisis. Journal of Management Development, 30(10), 1093 - 1112.

Md Jais, I., Azu Farhana, A. (2020): The significance of music to gifted students. Quantum Journal of Social Sciences and Humanities, 1(4): 33-43.

Md Jais, B.I., Loo, F.C., Rorlinda, Y, Mohd Sham, B.K. (2018): Comparison of Dalcroze Eurhythmics teaching approach with conventional approach to enhance kompang playing skills among Malaysian children. SSRG International Journal of Humanities and Social Science (SSRG-IJHSS), 5(6): 64-69.

Merriam, S. B. (1998). Qualitative research and case study applications in education. San Francisco: Jossey-Bass.

Mérida-López, S., \& Extremera, N. (2017). Emotional intelligence and teacher burnout: A systematic review. International Journal of Educational Research, 85, 121-130. 
Phillips, P. A., Page, S. J., \& Sebu, J. (2020). Achieving research impact in tourism: Modelling and evaluating outcomes from the UKs Research Excellence Framework. Tourism Management, 78, 104072.

Randell, S.S. (1999). Strategic human resource management. Wiley Blackwell.

Reddekopp, Therese. (2007). Linking the Teacher Appraisal Process to the School Improvement Plan. Principal Leadership.

Roger,S. (2014). Performance management- "Impacts \& Trends" White Paper, Development Dimensions international.

Rorlinda Yusof, Mohd Sham Kamis, Salleh Huddin Abdul Rashid, Noorlin Maaulot, Md Jais Ismail. (2020). Leadership characteristic of malaysian gifted and talented students: implication on islamic youth leadership. PalArch's Journal of Archaeology of Egypt / Egyptology, 17(6), 12385-12403. Retrieved from https://www.archives.palarch.nl/index.php/jae/article/view/3080

Susan, M. H. (2019). Common problems with performance appraisal. HR. Management Careers.

Susan, M. H. (2019). 5 tips to help managers improve performance appraisal. HR. Management Careers.

Swan, S. (2012). Ready-to-use performance appraisals. New York: John Wiley \& Sons.

Widyasari, W. (2019). Outstanding Teachers: The Steps In Acquiring Them. International Journal for Educational and Vocational Studies (IJEVS, 1(5), 440-447.

Xavier, J.V. (2015). A study on the effectiveness of performance appraisal system and its influence with the socio-demographic factors of the employees of a manufacturing industry in tamil nadu. International Journal of Research in Management \& Business Studies, 2 (1).

Zvavahera, P. (2015). An evaluation of the effectiveness of performance management systems on service delivery in the Zimbabwean civil service. 